\title{
Kekuatan Momen Penampang Komposit Girder I
}

\author{
Sungkono \\ Program Studi Diploma Teknik Sipil FTSP ITS \\ Email: sungkonokarsidi@yahoo.com
}

\begin{abstract}
Behavior of composite parts simple or continuous beam in the development of knowledge has been widely publicized. Wittry (1983) has become an important part of the specification RSNI (Indonesian National Standard Plan) T-03-2005, refer to the BMS-1992 and AASHTO (1994). Design of Composite steel and concrete bridge which refers to the specification, requiring a new alternative. Issues, there were constraints on The specification RSNI T-03-2005 that limit the use of the types of high-strength steel melting in the construction of bridge construction. Methods JY Aaron were reviewed, it has been developed by Yakel AJ and Azizinami A and proposed to be used in the specification AASTHO. The result show nominal moment is calculated with the method proposed JY Aaron larger than 1994 or RSNI methods of AASHTO T-03-2005, so it can be said that the method AASTHO (1994) is more conservative than the method proposed by Aaron JY (2005). Ductility ratio Hp / H 'from AASHTO greater than Aaron methods JY, 1.36> 1.105. For structural steel A709 Quality 345, it shown from the different uses of ductility modification factor of $0.7 / 7.5=0.09$ for AASTHO (1994) and a $1 / 8.7=0.11$ for the proposed method. Therefore, it would affect the value of strong nominal moment. Torque force reduction factor $=\left(H_{-} p-H^{\prime}\right) /\left(10 H_{-} p-5 H^{\prime}\right)^{\prime \prime} ; 1 \leq \mathrm{Hp} / \mathrm{H}^{\prime} \leq$ $5 ; "$ r value range is $0 \%$ to $9 \%$.
\end{abstract}

Keywords: strength moments, composite beam, girder bridge.

Abstrak

Perilaku bagian komposit balok sederhana maupun menerus dalam perkembangan pengetahuan telah banyak dipublikasikan. Publikasi oleh Wittry (1983) telah menjadi bagian penting dalam spesifikasi RSNI (Rencana Standar Nasional Indonesia) T-03-2005, mengacu pada BMS-1992 dan AASHTO (1994). Perencanaan jembatan komposit baja beton yang mengacu pada spesifikasi tersebut, membutuhkan Alternatif baru. Permasalahan, pada spesifikasi RSNI T-032005 mengandung kendala yang membatasi pemakaian jenis-jenis baja berkekuatan leleh tinggi dalam pembangunan konstruksi jembatan. Metode usulan Aaron JY yang ditinjau, telah dikembangkan oleh Yakel AJ dan Azizinami A dan diusulkan untuk digunakan dalam spesifikasi AASTHO. Hasil studi ini menunjukkan bahwa momen nominal yang dihitung dengan metode usulan Aaron JY lebih besar daripada metode AASHTO 1994 atau RSNI T-03-2005, sehingga bisa dikatakan bahwa metode AASTHO (1994) lebih konservatif dari metode yang diusulkan oleh Aaron JY (2005). Rasio daktilitas Hp/H' dari AASHTO lebih besar daripada metode Aaron JY, 1,36 > 1,105. Untuk baja struktural A709 Mutu 345, ini bisa dilihat dari perbedaan penggunaan faktor modifikasi daktilitas yaitu $0,7 / 7,5=0,09$ untuk AASTHO (1994) dan $1 / 8,7=0,11$ untuk metode usulan. Oleh karena itu, akan mempengaruhi nilai kuat momen nominal. Faktor reduksi kekuatan momen $=\left(H \_p-H^{\prime}\right) /\left(10 H \_p-5 H^{\prime}\right) \quad " ; 1 \leq \mathrm{Hp} / \mathrm{H}^{\prime} \leq 5$;" rentang nilai $\mathbf{r}$ adalah $0 \%$ sampai dengan $9 \%$.

Kata kunci: kekuatan momen, balok komposit, jembatan girder.

\section{Pendahuluan}

Struktur geologi tanah Propinsi Jawa Perkembangan pengetahuan mengenai perilaku bagian-bagian komposit suatu balok sederhana maupun balok menerus telah tersedia dalam berbagai tulisan yang dimuat dalam publikasi ilmiah. Salah satu publikasi ilmiah, hasil karya Wittry (1993) telah menjadi bagian penting dalam spesifikasi RSNI (Rencana Standar Nasional Indonesia)
T-03-2005. Konsep RSNI ini mengacu pada BMS-1992 dan AASHTO (1994). Dalam perencanaan jembatan komposit baja beton yang mengacu pada spesifikasi RSNI T-03-2005 "Perencanaan Stuktur Baja untuk Jembatan", ini membutuhkan suatu penyegaran dan penyesuaian pada bagian-bagian yang termaktub dalam spesifikasi. Untuk itu harus mengikuti perkembangan pengetahuan dan penelitian baru. Pada spesi- 
fikasi RSNI T-03-2005 mengandung kendala yang membatasi pemakaian jenis-jenis baja berkekuatan leleh tinggi dalam pembangunan konstruksi jembatan. Keterbatasan ini berkenaan dengan kekuatan lentur dan daktilitas balok komposit berkekuatan leleh lebih dari $345 \mathrm{MPa}$, misalnya jenis baja BJ 55 .

\section{Metodologi}

Pelat beton yang dipasang di atas balok baja telah banyak digunakan dalam jembatan komposit baja beton. Agar pasti menjadi berperilaku liat (daktil), komponen-komponen komposit harus diberi ukuran sedemikian rupa, hingga bisa dijamin pelelehan baja yang cukup memadai pada komponen penampang yang mengalami tegangan tarik sebelum beton mulai hancur. Ketentuan dan syarat penjaminan jenis perilaku ini menjadi tujuan dari persyaratan-persyaratan dalam Spesifikasi RSNI T-032005. Perencanaan balok komposit yang menggunakan jenis baja kekuatan tinggi membuat penampang yang punya kapasitas pikul beban lebih baik tanpa menambah ukuran komponenkomponen struktur. Jadi, semakin tinggi kekuatan baja, ini harus diimbangi juga dengan kekuatan pelat beton yang memadai, karena kemungkinan besar beton akan menjadi hancur sebelum komponen-komponen baja mengalami tegangan tarik dan regangan yang cukup agar memastikan berperilaku liat dalam komponen-komponen komposit.

Kapasitas momen lentur penampang komposit menurut analisis plastis harus diperhitungkan pada saat kejadian pelengkungan yang sangat besar pada balok. Akibatnya tegangan-tegangan tekan dalam penampang beton akan menjadi seragam sebesar $0,85 \times \mathrm{xc}^{\prime}$, dimana $\mathrm{fc}^{\prime}$ adalah kuat tekan beton pada umur 28 hari (lihat Gambar 1a), dan seluruh penampang baja menjadi leleh baik tegangan-tegangan tekan ataupun tarik, bergantung pada letak sumbu netral. Penampang beton yang mengalami tegangan tarik biasanya diabaikan. Penyebaran tegangan berkenaan dengan momen plastis sederhana digambarkan pada gambar $1 b$.

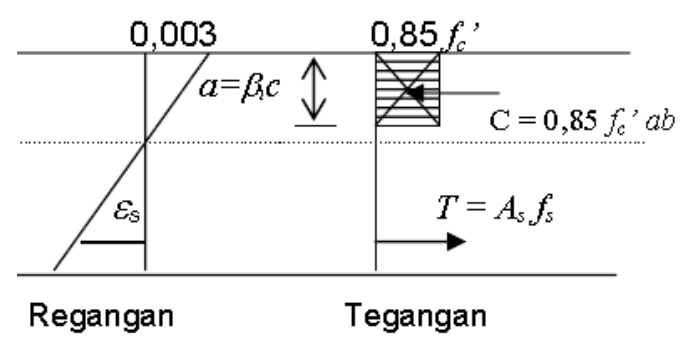

(a)

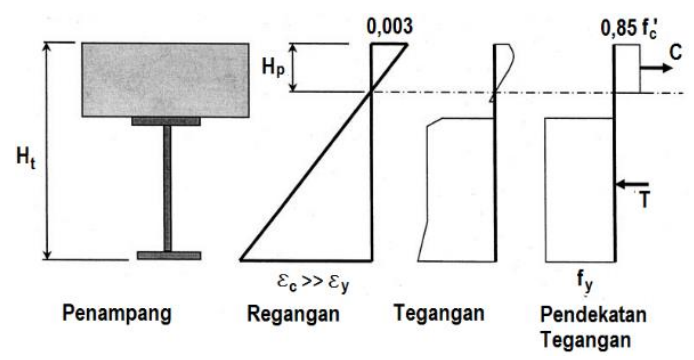

(b)

Gambar 1. (a) Sebaran regangan tegangan dalam beton; (b) Sebaran regangan tegangan dalam penampang komposit

Model analisis plastis ini hanya berlaku pada penampang-penampang baja yang cukup kompak dan diberi penahan kesamping secara baik, dikarenakan dalam pusat elastis penampang memiliki regangan hampir nol. Kekurangan pelelehan bahan dalam pusat elastis penampang atau dekat sekitar sumbu netral akan mengakibatkan penurunan kekuatan lentur yang akan diimbangi oleh pengerasan regangan, dalam jumlah kecil, yang terjadi di serat bawah tepi penampang. Pengerasan regangan ini diijinkan terjadi sebab dijamin oleh persyaratan kekompakan dan pengekangan, jadi ini mungkin akan diperoleh pelengkungan balok yang besar. 
Kehancuran beton dapat membatasi pelengkungan balok komposit yang mungkin bisa terjadi, maka ini akan menjadi kendala hingga tidak terpenuhinya asumsi analisis penampang yang mengharuskan terjadi pelengkung-an balok yang sangat besar. Pada umumnya bila sumbu netral semakin dekat pada sayap tarik dengan ketinggi-an penampang total yang diketahui, maka regangan sayap tarik maksimum yang diperoleh akan semakin rendah. Hal ini membatasi pengerasan regangan yang dapat disediakan untuk membantu mengatasi kekuatan yang kurang akibat pelelehan bahan dekat sumbu netral yang semakin mengecil, sehingga momen ultimit lebih rendah daripada $M_{p}$ teoritis yang dihitung.

Dengan memperhatikan penyebaran regangan tegangan yang ditunjukkan pada Gambar 1, tampak berbeda dari apa yang diasumsikan dalam perencanaan beton bertulang, seperti termaktub dalam SNI 03-2847-2002, Tata Cara Perhitungan Struktur Beton untuk Bangunan Gedung dimana tinggi blok tegangan tekan persegi ekivalen beban diambil sebagai faktor $\beta_{1}$ dikalikan dengan kedalaman sumbu netral. Ketentuan-ketentuan dalam spesifikasi RSNI T-03-2005 yang mengatur perhitungan $M_{p}$ pada bagian- bagian komposit memerlukan penerapan metode yang sama dengan yang tercantum dalam SNI 03-2847-2002 dan SNI T-12-2004, yang selanjutnya akan disebut metode PBB (Perhitungan Beton Bertulang). Namun, pada pasal 8.3 dari RSNI T-03-2005, yang menyediakan persamaan-persamaan untuk menghitung $M_{p}$, memanfaatkan pendekatan yang dijelaskan sebelumnya, seperti yang digambarkan dalam Gambar 1. Metode ini selanjutnya akan disebut sebagai metode sederhana. Untuk penampang-penampang yang sumbu netralnya, sebagaimana yang dicari kedudukannya dengan metode SNI 03-2847-2002, terletak jatuh dalam dek, momen yang diprediksi dari dua metode itu adalah sama. Walaupun begitu, letak sumbu netral berlainan dengan faktor blok tegangan $\beta_{1}$, yang digunakan dalam metode PBB, berkisar antara dari 0,85 untuk kekuatan beton di bawah $30 \mathrm{MPa}$ sampai dengan 0,65 untuk kekuatan beton lebih dari $55 \mathrm{MPa}$. Untuk bagian-bagian dengan seluruh penampang pelat lantai beton dalam tegangan tekan, kedua metode tersebut sependapat mengenai momen plastis maupun letak sumbu netral. Bagian-bagian lain yang tersisa merupakan peralihan antara dua kondisi ekstrim. Dalam semua kasus, nilai momen plastis serupa, atau berbeda dalam beberapa persen, baik menggunakan masingmasing metode. Namun, letak sumbu netral dapat berbeda sebanyak 35\% untuk beton mutu tinggi. Fakta ini mengakibatkan pemilihan metode untuk mencari letak sumbu netral sangat penting, karena ketentuanketentuan perencanaan yang aman mengupayakan menemukan hubungan antara kekuatan dengan kedalaman sumbu netral.

Kedua metode, metode PBB dan metode sederhana, telah digunakan dalam penelitian tentang posisi sumbu netral di waktu yang lalu. Ansourian (1982), sudah mengembangkan parameter daktilitas, sebagaimana yang akan segera dibahas, menggunakan metode PBB, sedangkan Wittry (1993), telah membuat modifikasi untuk parameter daktilitas Ansourian ini, menggunakan metode sederhana dalam menggambarkan posisi sumbu netral.

Meskipun daktilitas dan momen ultimit suatu penampang bisa diperoleh dari 
hubungan momen kelengkungan penampang, analisis ini tidak dilakukan dalam situasi perencanaan. Rotter dan Ansourian (1979) mengembangkan suatu kriteria untuk menjamin daktilitas penampang tanpa melakukan analisis kelengkungan momen. Dasar kriteria itu bahwa baja harus mulai timbul pengerasan regangan sebelum beton hancur. Kriteria itu berasal dari pengasumsian sebuah regangan hancur beton ( $\left.\varepsilon_{u}\right) 0,003 \mathrm{~mm} / \mathrm{mm}$ dan sebuah pengerasan regangan baja $\left(\varepsilon_{s h}\right) \quad 0,012$ $\mathrm{mm} / \mathrm{mm}$ pada serat bawah sayap tarik. Dengan menggunakan penyebaran regangan ditunjukkan pada Gambar 2, kedalaman sumbu netral minimal $\left(H_{\text {Min }}\right)$ diperlukan untuk mengembangkan pengerasan regangan dapat diperoleh dengan menggunakan:

$H_{\text {Min }}=H_{b}=\frac{\varepsilon_{u}}{\varepsilon_{u}+\varepsilon_{s h}} H_{t}=\frac{0,003}{0,001+0,012} H_{t}=\frac{H_{t}}{5}$

dimana $H_{t}=$ tinggi penampang total dari serat atas beton sampai serat bawah baja.
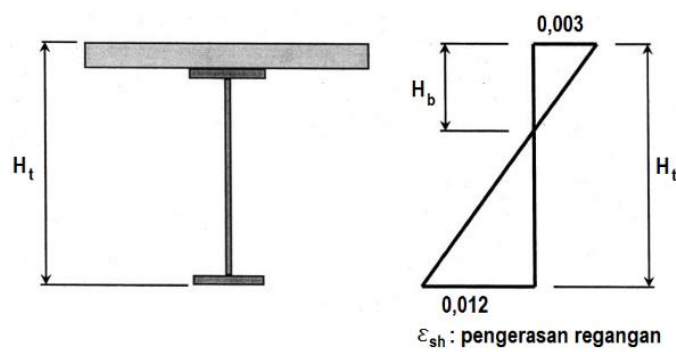

Gambar 2. Asumsi sebaran regangan

Ansourian (1982) mendefinisikan parameter daktilitas untuk balok komposit sebagai batas rasio untuk kedalaman sumbu netral, $H_{\text {Min }}$, seperti yang didefinisikan sebelumnya, terhadap kedalaman sumbu netral yang sebenarnya pada saat runtuh, $H_{p}$. Berdasarkan hasil tes empat balok skala penuh dan studi numerik yang menyertainya, Ansourian menetapkan bahwa parameter daktilitas adalah indikator yang baik untuk daktilitas penampang. Selanjut- nya, berdasarkan analisis numerik, ditetapkan bahwa parameter daktilitas minimum 1,4 akan memberikan daktilitas yang cukup untuk mendapatkan beban runtuh plastis pada kombinasikombinasi terburuk dari bentang dan pembebanan. Kesimpulan ini tercermin dalam spesifikasi RSNI T-03-2005 definisi $H^{*}$ [lihat Persamaan. (2)], adalah $H_{\text {Min }}$ dibagi dengan 1,5. Nilai 1,4 telah dibulatkan menjadi 1,5 dalam spesifikasi RSNI T-03-2005:

$H^{*}=\frac{H_{\mathrm{Vim}}}{1,5}=\frac{H_{\mathrm{t}}}{1,5 \times 5}=\frac{H_{\mathrm{t}}}{7,5}$

Ketentuan daktilitas yang ada pada spesifikasi RSNI T-03-2005 untuk balok jenis baja BJ 34, BJ 37, BJ 41, BJ 50, BJ 55 berdasarkan pada hasil karya Wittry (1993) di Universitas Texas, Austin. Wittry menggunakan karya Ansourian sebagai landasan dan menyelidiki efek dari sifat material pada hasil-hasilnya.

Wittry telah menyelidiki berbagai macam rasio daktilitas dari banyak bagian baja komposit hipotetis, yang didefinisikan sebagai $H_{p} / H^{*}$ dimana $H_{p}$ = kedalaman sumbu netral penampang tertentu yang diperoleh dari analisis. Perhatikan bahwa rasio daktilitas, sebagaimana dimaksud oleh Wittry dan spesifikasi RSNI T-03-2005, sama dengan 1,5 dibagi dengan parameter daktilitas Ansourian ini. Wittry menemukan bahwa, pada $H_{p} / H^{*}=1$, kapasitas momen kurang dari momen plastis teoritis $\left(M_{p}\right)$ untuk bahan baja dengan $f_{y}$ sama dengan 250 dan 345 MPa. Kemudian Wittry menyarankan mengganti faktor daktilitas, $H^{*}$, dengan faktor daktilitas modifikasi, $H^{\prime}$, yang diberikan oleh persamaan berikut:

$$
\begin{aligned}
& H^{s}=0,7 \frac{H_{t}}{7,5} ; \quad f_{y}>250 \mathrm{MPa} \\
& H^{s}=0,9 \frac{H_{t}}{7,5} ; \quad f_{y} \leq 250 \mathrm{MPa}
\end{aligned}
$$




\section{ISSN.1907-753X}

Nilai-nilai 0,7 dan 0,9 pada persamaan $H^{\prime}$ dapat diartikan sebagai faktor yang menjelaskan pengaruh kurva teganganregangan pada daktilitas penampang komposit jenis baja tertentu. Spesifikasi RSNI T-03-2005 mengacu pada faktor-faktor ini yaitu $\beta$. Jika nilai rasio daktilitas modifikasi, $H_{p} / H^{\prime}$ sama dengan satu, maka kapasitas momen kira-kira sama dengan $M_{p}$. Wittry juga mengusulkan metode untuk menghitung kapasitas momen penampangpenampang komposit, dengan rasio daktilitas yang lebih besar dari satu, sebagai berikut:

$M_{u}=\frac{5 M_{p}-\Phi M_{y}}{4}+\frac{\Phi M_{y}-M_{p}}{4}\left(\frac{H_{p}}{H^{r}}\right) \leq M_{p}$

dimana $\varphi=0,85 ; H_{p} / H^{\prime} \leq 5 ;$ dan $\mathrm{My}=$ momen leleh penampang komposit. Rumus prediksi merupakan pencocokan linear dari $M_{p}$, bila $0<H_{p} / H^{\prime} \leq 1$, maka $M_{n}=M_{p}$, bila $H_{p} / H^{\prime}=5$, maka $M_{n}=0,85 M_{y}$ seperti pada gambar 3 .

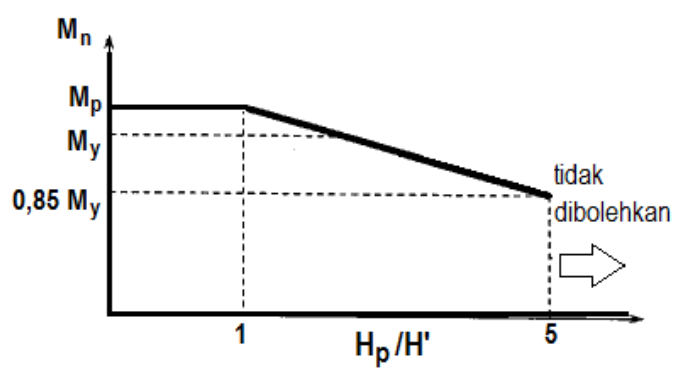

Gambar 3. Prakiraan kekuatan momen

Titik teratas berasal dari definisi $\beta$. Artinya, $\beta$ dipilih untuk masing-masing jenis bahan baja bahwa kekuatan momen maksimum sama dengan $M_{p}$ bila $H_{p} / H^{\prime}$ sama dengan 1 . Titik terendah dalam rumus itu terletak pada kekuatan momen maksimum sama dengan $M_{y}$ seperti yang diperoleh dari kecocokan linear melalui hasil-hasil numerik dari 20 penampang jembatan bentang pendek tidak liat. Penyelidikan tersebut telah dikerjakan oleh Wittry. Dia me- nemukan bahwa kapasitas momen diprediksi sebesar $M_{y}$ yang terjadi pada $H_{p} / H^{\prime}$ sama dengan 5. Akhirnya, kapasitas momen ini harus dikurangi dengan faktor 0,85 untuk memperhitungkan mode kegagalan tidak liat yang diprediksi pada balok dengan proporsi tersebut.

Aaron JY (2005) telah mengembangkan persamaan-persamaan prakiraan kuat seperti berikut ini:

- Katagori I dan II: sumbu netral dalam pelat beton atau pertengahan atas dari sayap tekan

$$
r=\frac{H_{p}-H^{r}}{10 H_{p}-5 H^{r}}
$$

- Katagori III: sumbu netral dalam badan baja

$$
\begin{aligned}
& r=\frac{1}{50}\left(\frac{H_{p}}{H^{r}}\right) \text { untuk } 250,345 \mathrm{MPa} \\
& r=\frac{1}{50}\left(\frac{H_{p}}{H^{r}}\right) \text { untuk } 485 \mathrm{MPa}
\end{aligned}
$$

Dia telah memodifikasi faktor daktilitas Wittry, untuk mengakomodasi baja kinerja tinggi $485 \mathrm{MPa}$ dengan memakai $\alpha$ (parameter penskala bahan)

$H^{\prime}=\frac{H_{t}}{\alpha} ; f_{y t}=\left\{\begin{array}{l}250 \mathrm{MPa} \rightarrow \alpha=6,5 \\ 345 \mathrm{MPa} \rightarrow \alpha=8,7 \\ 485 \mathrm{MPa} \rightarrow \alpha=7,5\end{array}\right.$

$H^{\prime}=$ modifikasi faktor daktilitas Aaron

Persamaan dasar penghitungan kuat momen prakiraan adalah

$M_{n}=M_{p}(1-r) \leq M_{p}$

$r=$ reduksi kekuatan momen

Penentuan momen leleh $M_{y}$, momen plastis $M_{p}$ dan momen nominal $M_{n}$ dari sebuah gelagar komposit baja-beton untuk daerah lentur positif, seperti berikut:

1. Menentukan Lebar Sayap Efektif

AASHTO pasal 4.6.2.6

$b_{s}=b_{\text {efeltif }}=$ lebih kecil dari $\left\{\begin{array}{c}L_{s / 4} \\ 12 t_{s}+{ }^{b_{f}} / 2 \\ s\end{array}\right.$

RSNI T-03-2005 pasal 8.2.1 
$b_{p}=$ lebih kecil dari $\left\{\begin{array}{c}L_{\theta / 7} \\ 12 t_{p}+{ }^{t_{f} / 2} \\ S\end{array}\right.$

2. Menghitung Sifat-sifat Penampang Komposit Elastis.

- penampang baja

$$
\begin{aligned}
y_{s b} & =\frac{\sum A_{i} y_{i}}{\sum A_{i}} ; y_{s t}=H-y_{s b} ; \\
I_{\text {gelagar }} & =\sum_{I_{\text {gelagar }}} I_{o}+\sum A_{i}\left(y_{i}-y_{s b}\right)^{2} \\
S_{s b} & =\frac{I_{\text {gelagar }}}{y_{s t}}
\end{aligned}
$$

- penampang komposit jangka pendek

$$
\begin{aligned}
& y_{s b-n}=\frac{\sum A_{i} y_{i}}{\sum A_{i}} ; y_{s t-n}=H-y_{s b-n} ; \\
& I_{k o m-n}=\sum I_{o}+\sum A_{i}\left(y_{i}-y_{s b-n}\right)^{2} \\
& \mathrm{~S}_{\mathrm{sb}-\mathrm{n}}=\frac{\mathrm{I}_{\mathrm{kom}-\mathrm{n}}}{\mathrm{y}_{\mathrm{sb}-\mathrm{n}}} ; \mathrm{S}_{\mathrm{st}-\mathrm{n}}=\frac{\mathrm{I}_{\mathrm{kom}-\mathrm{n}}}{\mathrm{y}_{\mathrm{st}-\mathrm{n}}}
\end{aligned}
$$

- penampang komposit jangka panjang

$$
\begin{aligned}
& y_{s b-3 n}=\frac{\sum A_{i} y_{i}}{\sum A_{i}} ; \\
& y_{s t-3 n}=H-y_{s b-3 n} ; \\
& I_{k o m-3 n}=\sum I_{o}+\sum A_{i}\left(y_{i}-\right. \\
& \left.y_{s b-n}\right)^{2} \\
& \mathrm{~S}_{s b-n}=\frac{\mathrm{I}_{\mathrm{kom}-\mathrm{n}}}{\mathrm{y}_{s \mathrm{~b}-\mathrm{n}}} ; \mathrm{S}_{\mathrm{st}-\mathrm{n}}=\frac{\mathrm{I}_{\mathrm{kom}-\mathrm{n}}}{\mathrm{y}_{\mathrm{st}-\mathrm{n}}}
\end{aligned}
$$

3. Menghitung Momen Leleh $M_{y}$

$$
\begin{aligned}
& M_{A D}=S_{n}\left(F_{y}-\frac{M_{D 1}}{s_{s}}-\frac{M_{D z}}{s_{s n}}\right) ; \\
& M_{y}=M_{D 1}+M_{D 2}+M_{A D}
\end{aligned}
$$

4. Menghitung Kapasitas Momen Plastis $M_{p}$

- Kasus I, Sumbu Netral Plastis (SNP) didalam badan profil baja (kedalaman $\bar{Y}$ diukur dari serat atas badan profil baja ke SNP)

$$
\begin{array}{lr}
P_{t}+P_{y V} \geq P_{c}+P_{s}+P_{r b}+P_{r t} & D_{c p}=\text { ting } \\
\bar{Y}=\left(\frac{D}{2}\right)\left[\frac{P_{t}-P_{c}-P_{s}-P_{r b}-P_{r t}}{P_{w y}}+1\right] & \text { pada } \\
M_{p}=\frac{P_{w Y}}{2 D}\left[\bar{Y}^{2}+(D-\bar{Y})^{2}\right]+P_{r t} d_{r t}+P_{r b} d_{r b}+P_{s} d_{g}+P_{c} d_{c}+P_{t} d_{t}
\end{array}
$$

5. Menghitung Momen Nominal $M_{n}$

a. Memeriksa kekompakan penampang gelagar baja:

- Syarat kelangsingan badan

$$
\begin{aligned}
\frac{2 D_{c p}}{t_{w}} & \leq 3,76 \sqrt{\frac{E}{F_{y c}}} \\
D_{c p}= & \text { tinggi badan dalam tekan } \\
& \text { pada momen plastis } \\
t_{w}= & \text { tebal badan profil baja }
\end{aligned}
$$




\section{ISSN.1907-753X}

$$
\begin{aligned}
F_{y c}= & \text { Kuat leleh minimum yang } \\
& \text { disyaratkan dari sayap } \\
& \text { tekan }
\end{aligned}
$$

Sayap atas profil baja dikekang cukup memadai oleh pelat lantai beton yang mengeras; jadi tidak perlu persyaratan untuk kelangsingan sayap tekan dan pengekangan penampang-penampang komposit kompak pada keadaan kuat ultimit.

b. Memeriksa syarat daktilitas $H_{p} / H^{\prime} \leq$ 5

Maksud dari persyaratan ini adalah untuk mencegah secara tetap hancurnya pelat beton bilamana penampang komposit mendekati kapasitas momen plastisnya.

$H_{p}=$ jarak yang diukur dari serat atas pelat beton ke SNP.

$H^{\prime}=0,7 \frac{H_{t}}{7,5}$, penampang dengan $f_{y}$ $=345 \mathrm{MPa}$

$H^{\prime}=0,9 \frac{H_{t}}{7,5}$, penampang dengan $f_{y}$ $=250 \mathrm{MPa}$

c. Memeriksa batas rasio momen inersia

Batang lentur harus memenuhi persyaratan berikut:

$$
\begin{aligned}
& 0,1 \leq \frac{I_{Y C}}{I_{Y}} \leq 0,9 ; \quad I_{Y C}=\frac{t_{c} b_{c}^{\mathrm{a}}}{12} \\
& I_{Y}=\frac{t_{c} b_{c}^{\mathrm{a}}}{12}+\frac{D t_{W}^{\mathrm{a}}}{12}+\frac{t_{t} b_{t}^{\mathrm{a}}}{12}
\end{aligned}
$$

d. Kekuatan lentur nominal $M_{n}$

$$
M_{n}=\frac{5 M_{p}-0,85 M_{y}}{4}+\frac{0,85 M_{y}-M_{p}}{4}\left(\frac{D_{p}}{D^{\prime}}\right) \leq M_{p}
$$$$
\text { atau }
$$

$$
M_{n}=1,3 R_{h} M_{y} \leq M_{p}
$$

$R_{h}$ : faktor reduksi tegangan sayap, nilainya 1,0 untuk gelagar homogeny

\section{Metode Aaron JY}

Langkah 1 sampai dengan 4 sama dengan metode AASHTO, juga langkah 5 mirip dengan AASTHO, hanya bedanya pada modifikasi faktor daktilitas dan rumus persamaan kuat momen nominal

\section{Langkah 5 menghitung momen nominal $M_{n}$}

Kuat lentur nominal penampang kompak komposit dalam daerah lentur positif harus diperhitungkan sebagai berikut:

$$
\begin{aligned}
& M_{n}=M_{p}(1-r) \leq M_{p} \\
& M_{p}: \text { kuat lentur plastis } \\
& r: \text { reduksi kekuatan momen }
\end{aligned}
$$

- jika letak SNP dalam pelat lantai atau separuh sayap tekan bagian atas $r=\frac{H_{p}-H^{v}}{10 H_{p}-5 H^{\prime}}$ catatan: jika $H_{p} \leq H^{\prime}$, maka $M n=$ $M p$

- jika tidak (letak SNP dalam separuh sayap tekan bagian bawah atau badan profil baja) maka $r=\frac{1}{50}\left(\frac{H_{p}}{H^{r}}\right)$ untuk 250 dan $345 \mathrm{MPa}$ $r=\frac{1}{30}\left(\frac{H_{p}}{H^{r}}\right)$ untuk $485 \mathrm{MPa}$

Nilai $r$ tunduk pada batasan

$$
f_{y t}=\left\{\begin{array}{l}
\frac{H_{p}}{H^{\prime}} \leq 5,0 \text { dan } H^{\prime}=\frac{H_{t}}{\alpha} \\
250 \mathrm{MPa} \rightarrow \alpha=6,5 \\
345 \mathrm{MPa} \rightarrow \alpha=8,7 \\
485 \mathrm{MPa} \rightarrow \alpha=7,5
\end{array}\right.
$$

Selain itu, kuat lentur nominal boleh ditentukan dengan metode berikut:

Cara pendekatan:

$M_{n}=1,3 R_{h} M_{y}$

Cara teliti:

$M_{n}=R_{h} M_{y}+A\left|M_{n p}-M_{c p}\right|$

dimana $R_{h}=$ faktor hibrid ditetapkan dalam Pasal 6.10.4.3.1; $A$ = bentangbentang ujung, jarak dari tumpuan ujung ke lokasi penampang lintang yang ditinjau dalam bentang dibagi dengan panjang bentang, dan untuk bentang-bentang interior, 1,$0 ; M_{c p}=$ momen akibat pembebanan terfaktor pada tumpuan interior seiring dengan momen lentur positif maksimum di penampang lintang yang ditinjau $(\mathrm{kN} \cdot \mathrm{m})$; dan $M_{n p}=$ ketahanan lentur nominal di tumpuan interior $(\mathrm{kN} \cdot \mathrm{m})$ 
pada mana $\left(M_{n p}-M_{c p}\right)$ untuk bentangbentang interior harus diambil nilai yang lebih kecil pada salah satu ujung bentang.

Dimana metode teliti digunakan, momen positif yang selaras tidak boleh lebih dari $R_{h} M_{y}$ untuk pembebanan terfaktor yang menghasikan momen negatif maksimum pada tumpuan yang bersebelahan.

\section{Hasil dan Pembahasan}

Contoh pekerjaan desain jembatan gelagar pelat komposit baja-beton dengan tiga bentang menerus disajikan disini. Pekerjaan ini menirukan dari hasil karya Lian Duan (2000) untuk menghitung momen-momen leleh, plastis dan nominal dari jembatan gelagar pelat komposit. Selanjutnya dengan memakai metode alternatif yang telah diusulkan oleh Aaron JY (2005), dilakukan penghitungan untuk nilai-nilai momen nominal.

Jembatan gelagar pelat komposit tiga bentang menerus memiliki bentangbentang ujung sama panjang $L_{\text {ujung }}=$ 49,0 m dan satu bentang tengah $L_{\text {tengah }}$ $=64,0 \mathrm{~m}$. Bangunan atas lebarnya $B=$ 13,4 m. Elevasi, denah, dan potongan melintang yang khas ditunjukkan dalam Gambar 5.

Baja struktural: A709 Mutu 345; $\mathrm{F}_{\mathrm{yw}}=$ $\mathrm{F}_{\mathrm{yt}}=\mathrm{F}_{\mathrm{yc}}=\mathrm{F}_{\mathrm{y}}=345 \mathrm{MPa}$. Beton: $\mathrm{f}_{\mathrm{c}}{ }^{\prime}=$ $28,0 \mathrm{MPa} ; \mathrm{E}_{\mathrm{c}}=25.000 \mathrm{MPa}$; rasio mudulus $\mathrm{n}=8$. Beban-beban: Beban mati = gelagar pelat baja + lantai beton + pagar + lapis ulang aspal $75 \mathrm{~mm}$; Beban hidup = AASHTO HL-93 + beban dinamik ijin. Lantai: Tebal lantai beton direncanakan $t_{s}=275 \mathrm{~mm}$ dan tebal pinggul pelat lantai dengan serat atas baja $t_{h}=85 \mathrm{~mm}$.

Penampang baja di dalam daerah lentur positif:
Sayap atas: $b_{c}=460 \mathrm{~mm}, t_{c}=25 \mathrm{~mm}$ Badan: $D=2440 \mathrm{~mm}, \mathrm{t}_{\mathrm{w}}=16 \mathrm{~mm}$ Sayap bawah: $b_{t}=460 \mathrm{~mm}, \mathrm{t}_{\mathrm{c}}=45 \mathrm{~mm}$ Konstruksi: Tanpa penopang; panjang gelagar tanpa pengekang untuk sayap tekan $\mathrm{L}_{b}=6,1 \mathrm{~m}$.

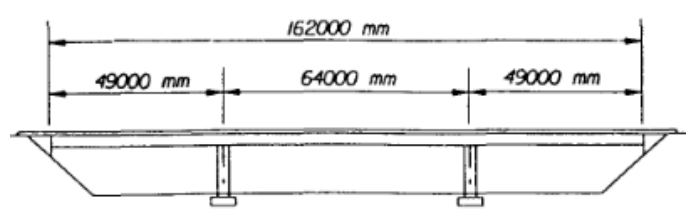

(a) Tampak

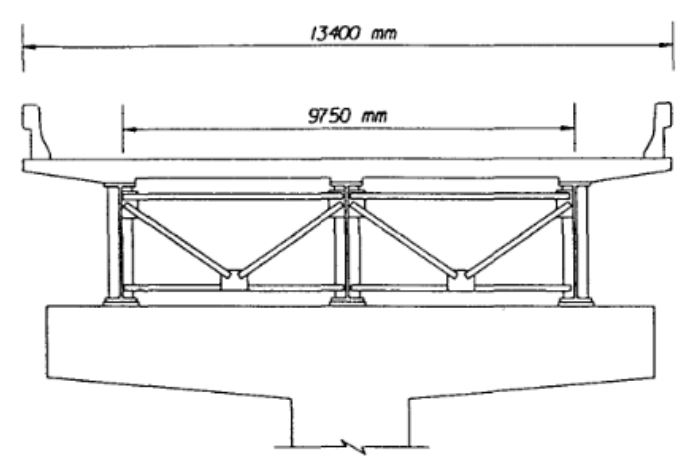

(b) Potongan

Gambar 5. Jembatan gelagar pelat komposit tiga bentang menerus

Baja struktural: A709 Mutu 345; $\mathrm{F}_{\mathrm{yw}}=$ $\mathrm{F}_{\mathrm{yt}}=\mathrm{F}_{\mathrm{yc}}=\mathrm{F}_{\mathrm{y}}=345 \mathrm{MPa}$. Beton: $\mathrm{f}_{\mathrm{c}}{ }^{\prime}=$ 28,0 MPa; $\mathrm{E}_{\mathrm{c}}=25.000 \mathrm{MPa}$; rasio mudulus $\mathrm{n}=8$. Beban-beban: Beban mati = gelagar pelat baja + lantai beton + pagar + lapis ulang aspal $75 \mathrm{~mm}$; Beban hidup = AASHTO HL-93 + beban dinamik ijin. Lantai: Tebal lantai beton direncanakan $t_{s}=275 \mathrm{~mm}$ dan tebal pinggul pelat lantai dengan serat atas baja $t_{h}=85 \mathrm{~mm}$.

Penampang baja di dalam daerah lentur positif:

Sayap atas: $b_{c}=460 \mathrm{~mm}, \mathrm{t}_{\mathrm{c}}=25 \mathrm{~mm}$ Badan: $D=2440 \mathrm{~mm}, \mathrm{t}_{\mathrm{w}}=16 \mathrm{~mm}$ Sayap bawah: $b_{t}=460 \mathrm{~mm}, t_{c}=45 \mathrm{~mm}$ Konstruksi: Tanpa penopang; panjang gelagar tanpa pengekang untuk sayap tekan $\mathrm{L}_{b}=6,1 \mathrm{~m}$.

Momen-momen positif maksimum dalam bentang tengah akibat beban- 


\section{ISSN.1907-753X}

beban berfaktor yang bekerja pada penampang baja dan penampang komposit jangka panjang masingmasing $M_{\mathrm{D} 1}=6.859 \mathrm{kN}-\mathrm{m}$ dan $M_{\mathrm{D} 2}=$ $2.224 \mathrm{kN}-\mathrm{m}$.

Menentukan momen leleh $M_{y}$, momen plastis $M_{p}$ dan momen nominal $M_{n}$ dari gelagar interior (tengah) untuk daerah lentur positif yaitu:

1. Menentukan Lebar Sayap Efektif (AASHTO pasal 4.6.2.6)

Untuk sebuah gelagar interior, lebar pelat lantai beton efektif adalah

$$
b_{s}=b_{\text {efektif }}=\text { lebih kecil dari }\left\{\begin{array}{c}
L_{e} / 4 \\
12 t_{s}+b_{f} / 2 \\
S
\end{array}\right.
$$

Dimensi penampang baja

\begin{tabular}{ccccc}
\hline \hline $\begin{array}{c}\mathrm{t}_{\mathrm{s}} \\
\mathrm{mm}\end{array}$ & $\begin{array}{c}\mathrm{t}_{\mathrm{h}} \\
\mathrm{mm}\end{array}$ & $\begin{array}{c}\mathrm{t}_{\mathrm{c}} \\
\mathrm{mm}\end{array}$ & $\begin{array}{c}\mathrm{b}_{\mathrm{c}} \\
\mathrm{mm}\end{array}$ & $\begin{array}{c}\mathrm{t}_{\mathrm{w}} \\
\mathrm{mm}\end{array}$ \\
\hline 275 & 85 & 25 & 460 & 16 \\
\hline \hline $\mathrm{D}$ & $\mathrm{tt}$ & $\mathrm{bt}$ & $\mathrm{Ht}$ \\
$\mathrm{mm}$ & $\mathrm{mm}$ & $\mathrm{mm}$ & $\mathrm{mm}$ \\
\hline 2440 & 45 & 460 & 2870 \\
\hline
\end{tabular}

Lebar efektif pelat lantai beton

\begin{tabular}{|c|c|c|c|c|}
\hline $\begin{array}{r}\mathrm{Le} \\
\mathrm{mm} \\
\end{array}$ & $\begin{array}{r}\mathrm{Le} / 4 \\
\mathrm{~mm} \\
\end{array}$ & $\begin{array}{c}\mathrm{S} \\
\mathrm{mm} \\
\end{array}$ & $\begin{array}{c}12 \mathrm{ts}+\mathrm{bfc} / 2 \\
\mathrm{~mm}\end{array}$ & $\begin{array}{c}\mathrm{bs}=\text { beff } \\
\mathrm{mm}\end{array}$ \\
\hline 35050 & 8763 & 4875 & 3250 & 3250 \\
\hline \multicolumn{5}{|c|}{ Sifat baja dan beton } \\
\hline $\begin{array}{c}\mathrm{F}_{\mathrm{y}} \\
\mathrm{MPa}\end{array}$ & & & $\begin{array}{c}\mathrm{E}_{\mathrm{c}} \\
\mathrm{MPa}\end{array}$ & $\mathrm{n}$ \\
\hline 345 & & & 25000 & 8 \\
\hline
\end{tabular}

2. Menghitung Sifat-sifat Penampang Komposit Elastis

Untuk penampang melintang pada lentur positif seperti ditunjukkan Gambar 6, sifat-sifat penampang elastis untuk non komposit, komposit jangka pendek $(\mathrm{n}=8)$ dan komposit jangka panjang $(3 n=24)$, dihitung dalam Tabel 1-3.

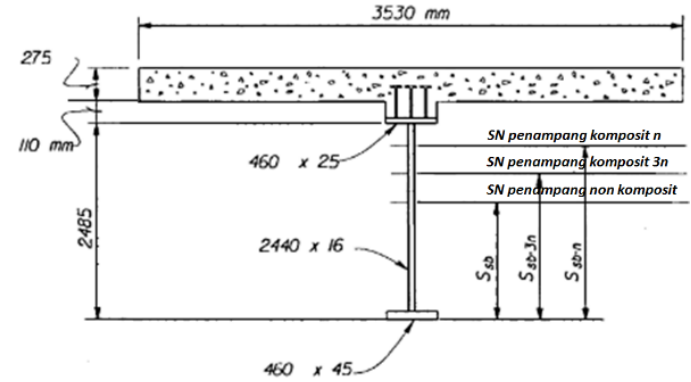

Gambar 6. Penampang lintang untuk momen lentur positif

Tabel 1. Sifat-sifat Penampang Baja (Non Komposit) untuk Daerah Lentur Positif

\begin{tabular}{lccc}
\hline \hline Komponen & $\begin{array}{c}\mathrm{A}_{\mathrm{i}} \\
\left(\mathrm{mm}^{2}\right)\end{array}$ & $\begin{array}{c}\mathrm{y}_{\mathrm{i}} \\
(\mathrm{mm})\end{array}$ & $\begin{array}{c}\mathrm{A}_{\mathrm{i}} \mathrm{y}_{\mathrm{i}} \\
\left(\mathrm{mm}^{3}\right)\end{array}$ \\
\hline 300x20 & 12.500 & 2.563 & $3,203 \mathrm{E}+07$ \\
2440x20 & 40.000 & 1.300 & $5,200 \mathrm{E}+07$ \\
600x50 & 32.500 & 2,5 & $8,125 \mathrm{E}+05$ \\
\hline Jumlah & 85.000 & & $8,484 \mathrm{E}+07$ \\
\hline \hline \multicolumn{5}{c}{$\mathrm{A}_{\mathrm{i}}\left(\mathrm{y}_{\mathrm{i}^{-}}\right.$} \\
\\
\hline \hline
\end{tabular}

$y_{s b}=\frac{\sum A_{\tilde{L}} y_{i}}{\sum A_{\tilde{i}}}=998,2 \mathrm{~mm}$

$y_{s t}=H-y_{s b}=1576,8 \mathrm{~mm}$

$I_{\text {gelagar }}=\sum I_{0}+$

$\sum A_{i}\left(y_{i}-y_{s b}\right)^{2}$

$$
=8.585 .000 \mathrm{~cm}^{4}
$$

$S_{s b}=\frac{I_{g e l a g a r}}{y_{s b}}=86.010 \mathrm{~cm}^{3}$

$S_{s t}=\frac{I_{\text {gelagar }}}{y_{s t}}=54.450 \mathrm{~cm}^{3}$

3. Menghitung Momen Leleh $M_{y}$

Momen leleh $M_{y}$ diperoleh dari pelelehan pertama kali dari salah satu sayap profil baja dan didapatkan berikut:

$M_{y}=M_{D 1}+M_{D 2}+M_{A D}$

$M_{D 1}$ adalah momen akibat bebanbeban tetap berfaktor pada penampang baja; 
$M_{D 2}$ adalah momen akibat bebanbeban tetap berfaktor, seperti permukaan aus dan pagar-pagar, pada penampang komposit jangka panjang;

$M_{A D}$ adalah momen akibat beban hidup tambahan yang menyebabkan pelelehan didalam sayap profil baja dan dapat diperoleh dari persamaan berikut:

$$
M_{A D}=S_{n}\left(F_{y}-\frac{M_{D 1}}{S_{s}}-\frac{M_{D 2}}{S_{3 n}}\right)
$$

Tabel 2. Sifat-sifat Penampang Komposit Jangka Pendek $n=8$

\begin{tabular}{|c|c|c|c|}
\hline \multicolumn{2}{|c|}{ Komponen } & $\begin{array}{cc}\mathrm{A}_{\mathrm{i}} & \begin{array}{c}\mathrm{y}_{\mathrm{i}} \\
\left(\mathrm{mm}^{2}\right)\end{array} \\
(\mathrm{mm})\end{array}$ & $\begin{array}{l}\mathrm{A}_{\mathrm{i}} \mathrm{y}_{\mathrm{i}} \\
\left(\mathrm{mm}^{3}\right)\end{array}$ \\
\hline baja & & $85.000998,2$ & $8.484 \mathrm{E}+07$ \\
\hline beton & & 101.600 & $2.793 \mathrm{E}+08$ \\
\hline \multirow[t]{2}{*}{$\begin{array}{l}\text { Jumlah } \\
\end{array}$} & \multicolumn{2}{|c|}{186.600} & $3.641 \mathrm{E}+08$ \\
\hline & $\begin{array}{r}\mathrm{yi}^{-} \mathrm{Y}_{\mathrm{sb}} \\
(\mathrm{mm}) \\
\end{array}$ & $\begin{array}{l}\mathrm{A}_{\mathrm{i}}\left(\mathrm{y}_{\mathrm{i}}-\right. \\
\left.\mathrm{y}_{\mathrm{sb}}\right)^{2} \\
\left(\mathrm{~mm}^{4}\right)\end{array}$ & $\begin{array}{c}\mathrm{I}_{\mathrm{o}} \\
\left(\mathrm{mm}^{4}\right)\end{array}$ \\
\hline \multirow{3}{*}{$\begin{array}{l}\text { baja } \\
\text { beton } \\
\text { Jumlah } \\
\end{array}$} & $-953,7$ & \multirow{2}{*}{$\begin{array}{l}7.731 \mathrm{E}+10 \\
6.470 \mathrm{E}+10\end{array}$} & $2.084 \mathrm{E}+10$ \\
\hline & 798,2 & & $5.290 \mathrm{E}+08$ \\
\hline & & $1.420 \mathrm{E}+11$ & $2.137 \mathrm{E}+10$ \\
\hline \multicolumn{3}{|c|}{$y_{s b-n}=\frac{\sum A_{i} y_{i}}{\sum A_{i}}=1951,8$} & $\mathrm{~mm}$ \\
\hline \multicolumn{4}{|c|}{$\begin{array}{l}y_{s t-n}=H-y_{s b-n}=623,2 \mathrm{~mm} \\
I_{k o m-n}=\sum I_{o}+\sum A_{i}\left(y_{i}-y_{s b-n}\right)^{2} \\
=16.340 .000 \mathrm{~cm}^{4} \\
S_{s b-n}=\frac{I_{k o m-n}}{v_{c h-n}}=83.700 \mathrm{~cm}^{3}\end{array}$} \\
\hline
\end{tabular}

Tabel 3. Sifat-sifat Penampang Kompo-sit Jangka Panjang $\mathrm{n}=24$

\begin{tabular}{|c|c|c|c|c|}
\hline \multicolumn{2}{|c|}{ Komponen } & $\begin{array}{c}\mathrm{A}_{\mathrm{i}} \\
\left(\mathrm{mm}^{2}\right)\end{array}$ & $\begin{array}{c}\mathrm{y}_{\mathrm{i}} \\
(\mathrm{mm})\end{array}$ & $\begin{array}{l}\mathrm{A}_{\mathrm{i}} \mathrm{y}_{\mathrm{i}} \\
\left(\mathrm{mm}^{3}\right)\end{array}$ \\
\hline baja & \multirow{2}{*}{\multicolumn{2}{|c|}{$\begin{array}{l}85.000 \\
33.850\end{array}$}} & 998,2 & $8.484 \mathrm{E}+07$ \\
\hline beton & & & $2.750,0$ & $9.310 \mathrm{E}+07$ \\
\hline \multirow[t]{2}{*}{ Jumlah } & \multicolumn{2}{|r|}{118.900} & & $1.779 \mathrm{E}+08$ \\
\hline & $\begin{array}{l}\mathrm{y}^{-}{ }^{-} \\
(\mathrm{m}\end{array}$ & & $\begin{array}{l}\mathrm{A}_{\mathrm{i}}\left(\mathrm{y}_{\mathrm{i}}-\right. \\
\left.\mathrm{y}_{\mathrm{sb}}\right)^{2} \\
\left(\mathrm{~mm}^{4}\right)\end{array}$ & $\begin{array}{c}\mathrm{I}_{\mathrm{o}} \\
\left(\mathrm{mm}^{4}\right)\end{array}$ \\
\hline baja & -495 & & $16 \mathrm{E}+10$ & $2.083 \mathrm{E}+10$ \\
\hline beton & 1.25 & & $14 \mathrm{E}+10$ & $1.763 \mathrm{E}+08$ \\
\hline Jumlah & & & $30 \mathrm{E}+10$ & $2.101 \mathrm{E}+10$ \\
\hline
\end{tabular}

$$
\begin{aligned}
& y_{s b-3 n}=\frac{\sum A_{i} y_{i}}{\sum A_{i}}=1.497,2 \mathrm{~mm} \\
& y_{s t-3 n}=H-y_{s b-3 n}=1.077,8 \mathrm{~mm} \\
& I_{k o m-3 n}=\sum I_{o}+\sum A_{i}\left(y_{i}-y_{s b-n}\right)^{2} \\
& \quad=9.531 .000 \mathrm{~cm}^{4} \\
& S_{s b-n}=\frac{I_{k o m-n}}{y_{s b-n}}=63.660 \mathrm{~cm}^{3} \\
& S_{s t-n}=\frac{I_{k o m-n}}{y_{s t-n}}=88.430 \mathrm{~cm}^{3}
\end{aligned}
$$

Untuk sayap atas

$$
M_{A D}=S_{s t-n}\left(F_{y}-\frac{M_{D_{1}}}{s_{s t}}-\frac{M_{D_{z}}}{s_{s t-s n}}\right)
$$$$
=50.829,38 \mathrm{kN}-\mathrm{m}
$$

Untuk sayap bawah

$$
\begin{aligned}
M_{A D} & =S_{s b-n}\left(F_{y}-\frac{M_{D_{1}}}{s_{s b}}-\frac{M_{D_{z}}}{s_{s b-s n}}\right) \\
& =19.278,96 \mathrm{kN}-\mathrm{m} \text { (kontrol) }
\end{aligned}
$$

Momen leleh

$$
\begin{aligned}
M_{y} & =M_{D 1}+M_{D 2}+M_{A D} \\
& =28.361,96 \mathrm{kN}-\mathrm{m}
\end{aligned}
$$

4. Menghitung Kapasitas Momen Plastis $M_{p}$

Pertama kali ditentukan dulu letak sumbu netral plastis (SNP) dengan mengabaikan baja tulangan pelat beton, sebagai berikut:

Gaya plastis pada penampang pelat lantai beton,

$P_{s}=0,85 f_{c}^{\prime} b_{s} t_{s}=19.337,50 \mathrm{kN}$

Gaya plastis pada penampang sayap profil baja bagian atas,

$P_{c}=P_{c 1}+P_{c 2}=F_{y c} b_{c} t_{c}=4.312,50$ $\mathrm{kN}$

Gaya plastis pada penampang badan profil baja,

$P_{w}=F_{y w} D t_{w}=13.800,00 \mathrm{kN}$

Gaya plastis pada penampang sayap profil baja bagian bawah,

$P_{t}=F_{y t} b_{t} t_{t}=11.212,00 \mathrm{kN}$

Oleh karena,

$P_{t}+P_{w} \geq P_{s}+P_{c} \Rightarrow 25.012,5>$ 23.650,0

maka SNP terletak dalam badan baja (Kasus I, kedalaman $\bar{Y}$ diukur dari serat atas badan baja ke SNP)

$\bar{Y}=\left(\frac{D}{2}\right)\left[\frac{P_{t}-P_{c}-P_{s}}{P_{\mathrm{w}}}+1\right]=123,4 \mathrm{~mm}$ 


\section{ISSN.1907-753X}

Momen plastis didapat dengan menjumlah semua gaya terhadap SNP, $M_{p}=\frac{P_{w}}{2 D}\left[\bar{Y}^{2}+(D-\bar{Y})^{2}\right]+P_{s} d_{s}+$ $P_{c} d_{c}+P_{t} d_{t}$ $d_{s}=323,4 \mathrm{~mm} ; d_{t}=2.401,6 \mathrm{~mm} ; d_{c}=$ $135,9 \mathrm{~mm} ; M_{p}=49.398,89 \mathrm{kN}-\mathrm{m}$

5. Menghitung Momen Nominal $M_{n}$ a. Memeriksa kekompakan penampang gelagar baja:

- Syarat kelangsingan badan

$\frac{2 D_{c p}}{t_{w}} \leq 3,76 \sqrt{\frac{E}{F_{y c}}} \Rightarrow 15,43<32,01$

$D_{c p}$ : atau $\bar{Y}$, tinggi badan dalam tekan pada momen plastis

$t_{w}$ : tebal badan profil baja

$F_{y c}$ : Kuat leleh minimum yang disyaratkan dari sayap tekan

Syarat kelangsingan badan terpenuhi.

- Hal yang wajar menganggap sayap atas profil baja dikekang cukup memadai oleh pelat lantai beton yang mengeras; dengan demikian, tidak perlu syarat untuk kelangsingan sayap tekan dan pengekangan penampangpenampang komposit kompak pada keadaan batas ultimit. Jadi penampang adalah sebuah penampang komposit kompak.

b. Memeriksa syarat daktilitas $D_{p} / D^{\prime} \leq$ 5

Maksud dari persyaratan ini adalah untuk mencegah secara tetap hancurnya pelat beton bilamana penampang komposit mendekati kapasitas momen plastisnya. $D_{p}$ adalah jarak yang diukur dari serat atas pelat beton ke SNP.

$D_{p}=448,41 \mathrm{~mm} ; D_{t}=2.875,0 \mathrm{~mm}$

$D^{\prime}=0,7 \frac{D_{t}}{7,5} \Rightarrow$ untuk $F_{y}=345 \mathrm{MPa}$

$D^{\prime}=268,3 \mathrm{~mm} ; D_{p} / D^{\prime} \quad=1,67<$

5 (ok)

c. Memeriksa batas rasio momen inersia

Batang lentur harus memenuhi syarat berikut:

$$
0,1 \leq \frac{l_{Y C}}{l_{Y}} \leq 0,9
$$

dimana $I_{y c}$ dan $I_{y}$ masing-masing adalah momen-momen inersi sayap tekan dan gelagar profil baja terhadap sumbu vertikal dalam bidang badan. Pembatasan ini menjamin bahwa rumus-rumus tekuk puntir lateral adalah benar berlaku.

$I_{Y C}=\frac{t_{c} b_{c}^{\mathrm{s}}}{12}=26.041,67 \mathrm{~cm}^{4}$

$I_{Y}=\frac{t_{c} b_{c}^{\mathrm{s}}}{12}+\frac{D t_{W}^{\mathrm{s}}}{12}+\frac{t_{t} b_{t}^{\mathrm{s}}}{12}=140.600 \mathrm{~cm}^{4}$

$\frac{I_{Y C}}{I_{Y}}=0,185(\mathrm{ok})$

d. Kekuatan lentur nominal $M_{n}$ Dengan asumsi bahwa penampang diatas tumpuan adalah kompak:

$M_{n}=1,3 R_{h} M_{y} \leq M_{p}$ atau

$M_{n}=\frac{5 M_{p}-0,85 M_{y}}{4}+\frac{0,85 M_{y}-M_{p}}{4}\left(\frac{D_{p}}{D^{\prime}}\right) \leq$

$M_{p}$

dengan faktor reduksi tegangan sayap $R_{h}=1,0$ untuk gelagar homogen ini, akan diperoleh,

$M_{n}=36.870,54 \mathrm{kNm}<M_{p}=49.398,9$

$\mathrm{kNm}$ (kontrol) atau

$M_{n}=45.155,59 \mathrm{kNm}<M_{p}=49.398,9$

$\mathrm{kNm}$

Metode alternatif yang diusulkan oleh Aaron J. Yakel.

Kekuatan lentur nominal $M_{n}$ $M_{n}=M_{p}(1-r) \leq M_{p}$

\section{Simpulan}

Dari hasil analisa dapat disimpulkan sebagai berikut:

1. Hasil nilai-nilai momen nominal dihitung dengan metode usulan Aaron JY lebih besar daripada metode AASHTO 1994 atau RSNI T-03-2005, sehingga bisa dikatakan bahwa metode AASTHO (1994) lebih konservatif dari metode yang diusulkan oleh Aaron JY (2005). 
2. Rasio daktilitas $\mathrm{Hp} / \mathrm{H}^{\prime}$ dari AASHTO lebih besar daripada metode Aaron JY, 1,36 > 1,105.

Untuk baja struktural A709 Mutu 345 , ini bisa dilihat dari perbedaan penggunaan faktor modifikasi daktilitas yaitu $0,7 / 7,5=0,09$ untuk AASTHO (1994) dan $1 / 8,7=0,11$ untuk metode usulan. Oleh karena itu akan mempengaruhi nilai kuat momen nominal.

3. Faktor reduksi kekuatan momen $=\left(H \_p-H^{\prime}\right) /\left(10 H \_p-5 H^{\prime}\right) \quad " ; 1 \leq \mathrm{Hp}$ $/ \mathrm{H}^{\prime} \leq 5 ; "$ rentang nilai $\mathrm{r}$ adalah $0 \%$ sampai dengan $9 \%$

\section{Daftar Pustaka}

Abramson, Lee. W, Thomas S.Lee, SNI 03-2847-2002. Tata Cara Perhitungan Struktur Beton untuk Bangunan Gedung (Versi Beta). Bandung Desember 2002

SNI T-12-2004. Perencanaan Struktur Beton untuk Jembatan. Badan Standarisasi Nasional. Bandung Agustus 2003

RSNI T-03-2005. Perencanaan Struktur Baja untuk Jembatan. Badan Standarisasi Nasional. Yogyakarta: Beta Offset.

AASHTO, AASHTO LRFD Bridge Design Specifications. American Association of State Highway and Transportation Officials. Washington, D.C., 1994.

Aaron J. Yakel, Atorod Azizinamini. 2005. Improved Moment Strength Prediction of Composite Steel Plate Girders in Positive Bending. Journal of Bridge Engineering Jan 2005, Vol. 10, No. 1, pp. 28-38

Lian Duan, Yusuf Saleh, Steve Altman. 2000. Steel-Concrete Composite I-Girder Bridges. California Department of Transportation (C) 2000 by CRC Press LLC
Wittry, D. M., 1993. An analytical study of the ductility of steel concrete composite sections. MS thesis, Univ. of Texas at Austin, Austin, Tex.

Ansourian, P., 1982. Plastic rotation of composite beams, Journal Structural Division ASCE, 108(3), 643659.

Rotter, J. M., and Ansourian, P., 1979. Cross-section behavior and ductility in composite beams, Proceding, Institute of Civil Engineers, Part 2 Vol., 67, 453474 